\title{
NSF's proposed conflict-of-interest rules place burden on applicant and institution
}

Washington. US researchers would be required to disclose all relevant financial ties when submitting a grant application as part of a conflict-of-interest policy under consideration by the National Science Foundation (NSF). The proposed regulations, published on 16 July in the Federal Register, would also require institutions to have a comprehensive policy to deal with such potential conflicts.

If approved, the regulations would constitute the first such conflict-of-interest policy to be adopted by a US science agency. The National Institutes of Health withdrew a version they had circulated in 1989 after the academic community protested that it would cost millions of dollars to implement and would duplicate institutional policies in place at most universities (see Nature 343, $104 ; 1990$ ).

NSF, however, may have an easier time of it. Over the past three years, Congress has repeatedly urged the science agencies (and the academic community) to address the issue, despite the feeling that instances of significant conflicts of interest are rare. Most researchers "can see the writing on the wall", says one NSF official, and have accepted the idea that regulations are inevitable.

If such regulations must come, the proposal from the NSF may be the most palatable. As written, it is a way to gather data rather than an attempt to police research. According to the draft regulations, "NSF believes that significant conflicts of interests are rare in the work that NSF funds, [but] we have no data by which to demonstrate the point. The proposed policy would create a bank of data to serve as a reality check."

NSF expects disclosure (and a review by the institution) in cases where proposed research would evaluate or lead to a commercial product or where the research would be relevant to any outside commercial venture in which the investigator is involved. But it believes that few researchers will fall into either category, and that those who do should find it simple enough to disclose that fact. It estimates that the typical investigator should need only 20 minutes to complete the financial information.

The agency intends that the internal policies of universities and other institutions that receive NSF funds should deal with conflicts. It has not yet decided how it will handle a case of conflict that the applicant's institution has not adequately dealt with, or, for that matter, how it will identify such a case.

NSF would require institutions that receive grants to have a conflict-of-interest policy that, at the minimum, requires faculty and staff to disclose any 'significant' financial ties. Such a policy would include procedures to review any disclosures and to inform research sponsors both of any problems and how they have been resolved.

Under the proposed regulations, investigators would submit financial disclosures in a sealed envelope accompanying their grant application. The application would be reviewed for its scientific merit and the envelope opened only if the application were approved for funding. At that point, NSF's general counsel would review the disclosure for any possible conflicts using criteria yet to be drawn up.

The proposal has so far elicited little reaction. Part of that silence is due to its appearance at a time when many institutions are on holiday. The original deadline of 14 September has been extended to 14 October at the request of the Association of American Universities (AAU), an associa- tion of 58 major researcher universities in the United States and Canada, which plans to discuss the issue at a meeting on 8 September.

Those who have read the proposed regulations see few problems. Milton Goldberg, of the Washington-based Council on Government Relations, points out the ambiguity in the phrase "significant financial ties" and is concerned that the disclosures may become public through requests made under the federal Freedom of Information Act. NSF says it would try to block such requests.

But even Goldberg says that it is important to "separate the nuisance [to researchers] of doing this and its public-policy value". Getting hard data on the scope of the problem may clarify the issue, he says, and is worth some potential loss of privacy and inconvenience to scientists and their institutions.

Christopher Anderson

\section{Australia increases funds for grants and applied research}

Sydney. The Australian government will increase research spending next year by 2.2 per cent, according to budget figures released last week. The biggest winners are university scientists funded by the Australian Research Council, which will receive an increase of 9 per cent, while most government researchers will see their funding actually shrink. The overall science budget will grow to $A \$ 2.85$ billion (US\$2.1 billion), an increase of A\$149 million over 1992.

The government's budget is rarely changed once it is presented. And as the government is by far the largest supporter of science, its priorities tend to shape the direction of research in Australia.

For industry, the best news is the government's decision to abandon its plans to weaken the incentive for companies to invest in research. Cabinet ministers had decided to reduce the 150 per cent tax deduction that companies can claim for money spent on research and development, but the decision was reversed just days before the budget was unveiled after strong protests from the business and research communities.

In place of a smaller deduction, the government will tighten its rules to restrict the tax concessions to genuine investors in research projects, excluding those looking solely for a tax shelter. The government estimates that it will lose A $\$ 325$ million because of the deduction, which is intended to stimulate investments in research that will eventually bolster the economy.

The budget for the research council, which dispenses most of the federally funded grants under the country's centralized funding system, will increase to A \$269 million. Funds for agricultural research will rise by 13 per cent, to A $\$ 110$ million. The budget for cooperative research centres has been tripled, to A $\$ 54.5$ million, to accommodate several new university industry centres.

In contrast, the government continues to pare down its own research operations. The largest component, the Commonwealth Scientific and Industrial Research Organization (CSIRO), will have its budget reduced by 1 per cent, to A\$464 million. The CSIRO is expected to earn another A $\$ 220$ million from other sources; as a sign of its increasing reliance on the business community, it is moving its headquarters from the isolated federal capital of Canberra to Melbourne, the country's second-largest business centre.

The government has also issued a white paper (policy document) stressing the importance of applied research. The Prime Minister's Science Council is being renamed the Science and Engineering Council, and A\$6 million will be spent to create three advanced engineering centres to bring together university and industrial researchers.

Mark Lawson 